\title{
Novel Innovations in Floriculture Industry
}

\author{
V.B. Chavan*, S.P. Khedkar, B.R. Salvi, Y.R. Parulekar and N.V. Dalvi \\ Department of Horticulture, College of Agriculture, Dapoli, Dr. Balasaheb Sawant Konkan \\ Krishi Vidyapeeth, Dapoli-415 712, Ratnagiri (M.S), India \\ *Corresponding author
}

\begin{tabular}{|l|}
\hline Ke y w ord s \\
Innovation, Novel \\
and Industry
\end{tabular}

A B S T R A C T

There are several innovations in floricultural industry such as value addition in flowers, vertical garden, drying of flowers, hydroponics, aeroponics, bonsai, flower arrangement these add beauty in nature. Value addition in flowers not only help the producer to get a good price for its produces but also helps the consumer as they get a good quality as well quantity added products. Hydroponics is a technology for growing plants in nutrient solutions with or without the use of an artificial medium to provide mechanical support. Dry flowers and plant material have tremendous potential as substitute for fresh flowers and foliage for interior decorations. Methods of drying are sun drying, saw dust drying, pressing, polset polymer, silica driers. Flower arrangement is beautiful form of flower display. Flower arrangement is an organization of design and color towards creating an ambience using flowers, foliage and other floral accessories. Vertical garden are becoming popular in agro tourism centers. Trellises attached to the ground or to large space than traditional gardening requires. Floriculture is an emerging field in Indian Agriculture. Several innovations are emerging and becoming popular. These help to generates employment besides improving the quality of production. The innovation like vertical garden is becoming necessity to stop pollution and helps for cooling fresh air. However, this technique is highly specialized and requires systematic hands on treating for capacity building of agriculture graduate for rural use.

\section{Introduction}

Floriculture is one of the most important branches of ornamental horticulture. It is the fastest growing sector in Indian horticulture with annual expert of 20703.46 MT of 507.31 crores in 2017- 18 (APEDA) About 98 thousands ha was under cultivation in 200102 with a production of 556 thousand tonnes of loose flowers and 804 million number of cut flowers, which has been increased to
1,659 thousands loose flowers and 484 thousand tonnes cut flowers covering an area of 248.51 thousands ha. during 2015-16 (Indiastat). Cut greens refer to ornamental foliage and branches with or without decorative fruits, seed pods etc. to be used as fillers. Softening floral arrangements, provide contrast in floral arrangements. Complement the beauty of flowers. Fills voids or gap in floral designs used in bouquet making and flower arrangements to the extent of 20 to 25 
percent. In Global Status Europe is leading exporter in the world. Netherland is important trade hub for cut flowers and foliage. In foliage in Europe share about 60\% (CBI market informations Database 2013). The major cut foliage exporters in the world market are the Netherlands, USA, Costa Rice, Italy, Israel, Guatemala, Mexico, Germany, Canada, etc., The major importers are Norway, Germany, Denmark, USA, France, UK, Holland, Italy, Austria, and Japan (AIPH 2012).

In Indian status In terms of area of production, China and India have large total area is under flower cultivation More than $50 \%$ of the floriculture units are based in Karnataka, Andhra Pradesh, and Tamil Nadu. India is leading supplier of dry flower, dry and fresh foliage to Europe India's total export of floriculture was Rs. 507.31 crores/78.73 USD Millions in 2017-18The floral export from India comprises of dry flowers $(71 \%)$, fresh cut flowers (18\%), live plants $(9 \%)$, fresh bulbs (1\%).

\section{Varietal innovations}

\section{Use of molecular breeding for novelty}

Important ornamental character such as flower color, fragrance, and flower shape are clarified through isolation and analysis of related genes. Modification technology for these characters by genetic transformation is also developed. Basic breeding technologies that lead to improved breeding efficiency,

\section{Novelty in flower form}

Different strategies are being applied like hybridization, mutation, polyploidy, genetic engineering to bred the cultivars with new flower forms. Single, semi-double, and double types of flower are genetically controlled either by a single gene or multiple genes similarly, by induced mutagenesis, the mutant can be easily with modified visible characters such as flower shapes, size, or leaf form and growth habit.

\section{Novelty in flower color}

Color determined by four classes of pigments viz., Flavonoides, carotenoids, betalains and chlorophylls. Creation of novel flower colors employing genetic manipulation techniques. Transgenic carnation and roses accumulating delphinidin as a result of avonoid 3'5' hydroxylase gene expression and having novel blue hued flowers which have been commercialized.

Among various transgenic floricultural crops only roses and carnation have been commercialized. This indicates developed so far only colour by genetic engineering is still very challenging due to technical and economic difficulties

\section{Novelty in floral fragrance}

Flowers of many plant species emit floral scent to attract pollinators. Such sect are mixture aliphatic molecules (terpenoid, phenyl propanoid, benzenoid) (Pichersky and Dudareva, 2007). Chemical composition is varies according to species (Kundson et al., 1993). Several physiological and ecological studies have examined the floral functions of floral scent compounds in plant biology (Vainstein, 2002). Numerous cytological studies have been performed to determine scent glands and scent production and emission process (Bergougnoux et al., 2007).

Available functional geometric tools for Genetic engineering of floral scent

RNAi technology

Transgenics

Expressed sequence stage 


\section{Recent innovations}

\section{(Glow in the dark) Orchid}

The world's first genetically modified bioluminesecent is of Orchid. Successfully developed by Prof. Chia from the National Institute of Education (NIT).

To create bioluminescent orchid, Tissue are transformed from the Dendrobium genus using firefly luciferase gene. Using a method called "particle bombardment" The bioluminescent orchids will produce constant light. Light emit from roots, stem, leaves, and petals. Light intensity ranging from 5,000 to 30,000 photos per second.

\section{Bougainvillea - the source of grapheme}

Well known ornamentals. Have ability to resist pollutant in the air. Group of scientist of Pune found that high quality grapheme from these flowers by drying followed by chemical treatment. $30 \mathrm{gm} / \mathrm{kg}$ flower of bougainvillea. This discovery may make the batteries cheaper and long- lasting in near future.

\section{Aeroponics}

Aeroponic is the process of growing plants in the mist environment without the use of soil or an aggregate medium. The word "aeroponic" is derived from the Greek meaning of aero-(air) ponos - (labour) Aeroponic and soilless cultivation of A. and reanum was carried out in a climatic conditioned greenhouse. The aim to evaluate the productive and qualitative differences of the two growing systems. Aeroponic culture produced the highest number of leaves (29.7 vs. 17.9 per plant), with the maximum leaf size and petiole length. Soilless Anthuriums provided flowers with the widest spathe. Plants with cut roots showed lower values for all considered parameters than those with whole roots but evidenced a higher rhythm of root elongation during the experiment. Preliminary Results of Aeroponic Cultivation of Anthurium and reanum for Cut Flower Production

\section{Vertical garden}

A 'Green Wall', also commonly referred to as a 'Vertical Garden', Green wall technologies may be divided into two major categories: Green Facades and Living Walls. Vertical garden was invented by Stanley Hart White who patented a green wall system in the late 1930s.

\section{As a bio filtration}

An 'active' living wall is intended to be integrated into a building's infrastructure and designed to bio filter indoor air and provide thermal regulation. It is a hydroponic system fed by nutrient rich water which is recirculated from a manifold, located at the top of the wall, and collected in a gutter at the bottom of the fabric wall system. Plant roots are sandwiched between two layers of synthetic fabric that support microbes and a dense root mass. These root microbes remove airborne volatile organic compounds (VOCs), while foliage absorbs carbon monoxide and dioxide. The plants' natural processes produce cool fresh air that is drawn through the system by a fan and then distributed throughout the building. A variation of this concept could be applied to green facade systems as well, and there is potential to apply a hybrid of systems at a large scale.

\section{As a green building technology}

Vertical garden attached to exterior or interior walls of a building. They differ from green facades (ivy walls) as green walls have growing media supported on the face of the wall (Table 1-6). 


\section{Novelty in flower form}

\begin{tabular}{|c|c|c|c|c|}
\hline No. & $\begin{array}{l}\text { Breeding } \\
\text { methodology }\end{array}$ & Crop & Characteristics & Reference \\
\hline 1. & Hybridisation & Stock & Double flowers & Debener (1999) \\
\hline 2. & Mutation-Gamma rays & Chrysanthemum & $\begin{array}{l}\text { Spoon shaped, tubular and } \\
\text { irregular ray florets with } \\
\text { reduced flower head size }\end{array}$ & $\begin{array}{l}\text { Singh and Bala, } \\
2015\end{array}$ \\
\hline 3. & $\begin{array}{l}\text { Mutation- Heavy ion } \\
\text { beams }\end{array}$ & Carnation & Serrate to round petals & $\begin{array}{l}\text { Okamura et al., } \\
2003\end{array}$ \\
\hline 4. & $\begin{array}{l}\text { Mutation }- \text { gamma } \\
\text { rays }\end{array}$ & Bougain veillea & Variegated flower & Srivastva, 2002 \\
\hline 5. & Mutation- gamma rays & Gerbera & $\begin{array}{l}\text { Change in flower } \\
\text { morphology }\end{array}$ & Jain et al., (1998) \\
\hline 6. & $\begin{array}{l}\text { Polyploidy breeding } \\
\text { (colchicine induced) }\end{array}$ & Anthurium & $\begin{array}{l}\text { Stronger petioles, thicker } \\
\text { and deeper green leaves, } \\
\text { and thicker and longer } \\
\text { lived spathes in } \\
\text { tetraploides }\end{array}$ & Chen et al., 2011 \\
\hline 7. & $\begin{array}{l}\text { Rna-mediated } \\
\text { interference }\end{array}$ & Petunia hybrida & Double flower formation & $\begin{array}{ll}\text { Noor } & \text { et } \\
\text { al.,(2014) }\end{array}$ \\
\hline 8. & Mutation-Ion beams & Rose & $\begin{array}{l}\text { Change in number of } \\
\text { petals, shape and size }\end{array}$ & $\begin{array}{l}\text { Yamaguchi et } \\
\text { al., (2003) }\end{array}$ \\
\hline 9. & $\begin{array}{l}\text { Chimeric Repressor } \\
\text { gene-Silencing } \\
\text { Technology (CRES-T) }\end{array}$ & $\begin{array}{l}\text { Torenia chysanthemum, } \\
\text { morning glory, Cyclamen, Rose }\end{array}$ & $\begin{array}{l}\text { Modication of the flower } \\
\text { shape }\end{array}$ & $\begin{array}{l}\text { Shikata et al., } \\
2011 \text { Narumi et } \\
\text { al., } 2011 \text { Tanaka } \\
\text { et al., } 2011\end{array}$ \\
\hline
\end{tabular}

\section{RNAi Technology}

\begin{tabular}{|c|c|c|}
\hline Gene silenced & Scent compounds & Reference \\
\hline $\begin{array}{l}\text { PhBSMT } \\
\text { Petunia hybrid benzyl } \\
\text { Salicylate methyl } \\
\text { Transferase }\end{array}$ & $\begin{array}{l}\text { 1. Lack the major scent component } \\
\text { methyl benzoate } \\
\text { 2. Minimal changes in the emission of } \\
\text { other volatiles }\end{array}$ & $\begin{array}{l}\text { Under wood et al., } \\
(2005)\end{array}$ \\
\hline $\begin{array}{l}\text { (PhPAAS) } \\
\text { Pheny acetaldehyde } \\
\text { Synthase }\end{array}$ & $\begin{array}{l}\text { 1. Complete elimination of the } \\
\text { emission of phenyl acetaldehyde } \\
\text { 2. 2-phenyethanol (Pheyl acetaldehyde- } \\
\text { precursor) (Precursor of PAA) }\end{array}$ & $\begin{array}{l}\text { Kaminaga et al., } \\
\text { (2006) }\end{array}$ \\
\hline $\begin{array}{l}\text { (CFAT), Coniferyl alcohol } \\
\text { acyltransferase }\end{array}$ & $\begin{array}{l}\text { 1. Complete elimination of sioeugenol } \\
\text { 2. Little effect on the emission of other } \\
\text { Phelpropanoid / benzenoids volatiles }\end{array}$ & Dexter et al.,(2007) \\
\hline
\end{tabular}


Transgenics

\begin{tabular}{|l|l|l|l|l|}
\hline Approach & $\begin{array}{l}\text { Transgenic } \\
\text { species }\end{array}$ & Gene used & Results obtained & Referances \\
\hline Single gene & $\begin{array}{l}\text { Petunia } \\
\text { Carnation } \\
\text { Petunia }\end{array}$ & $\begin{array}{l}\text { CbLIS } \\
\text { CbLIS } \\
\text { RhAAT } \\
\text { (Rose) }\end{array}$ & $\begin{array}{l}\text { Linalyglucoside } \\
\text { Linalyl oxides } \\
\text { Benzyl acetate and phenyethyl } \\
\text { acetate }\end{array}$ & $\begin{array}{l}\text { Lucker } \text { et al.,(2001) } \\
\text { Lavt } \text { et al., (2002) } \\
\text { Guterman } \text { et al., } \\
(2006)\end{array}$ \\
\hline $\begin{array}{l}\text { Blocking of } \\
\text { competitive pathways }\end{array}$ & Carnation & $\begin{array}{l}\text { Anti- } \\
\text { DcF30H }\end{array}$ & $\begin{array}{l}\text { INCREASED } \\
\text { Methylbenzoate emission }\end{array}$ & Zuker et al.,(2002) \\
\hline $\begin{array}{l}\text { Down-regulation of } \\
\text { transcription factor }\end{array}$ & Petunia & PhODO1 & $\begin{array}{l}\text { Reduced levels of volatile } \\
\text { benzenoides }\end{array}$ & $\begin{array}{l}\text { Verdonk } \text { et } \\
\text { al.,(2005) }\end{array}$ \\
\hline
\end{tabular}

Table.1 "Effect of gamma irradiation on morphological characters of marigold (Tagetes erecta L.)"

\begin{tabular}{|c|c|c|c|c|c|c|c|c|}
\hline Sr. No. & $\begin{array}{c}\text { Treatmen } \\
\text { t No. }\end{array}$ & Treatments & $\begin{array}{c}\text { Plant } \\
\text { height }\end{array}$ & $\begin{array}{c}\text { No.of } \\
\text { branches } \\
\text { per plant }\end{array}$ & $\begin{array}{c}\text { Days } \\
\text { require for } \\
\text { flower } \\
\text { opening }\end{array}$ & $\begin{array}{c}\text { Diamet } \\
\text { er of } \\
\text { flower }\end{array}$ & $\begin{array}{c}\text { No. of } \\
\text { flower } \\
\text { per plant }\end{array}$ & $\begin{array}{c}\text { Survival } \\
\text { percenta } \\
\text { ge }\end{array}$ \\
\hline $\mathbf{1 .}$ & T1 & Control & 57.39 & 4.53 & 10.80 & 4.91 & 31.13 & 100 \\
\hline $\mathbf{2 .}$ & T2 & $25 \mathrm{~Gy}$ & 55.68 & 6.13 & 10.40 & 5.14 & 37.20 & 100 \\
\hline $\mathbf{3 .}$ & T3 & $50 \mathrm{~Gy}$ & 54.31 & 5.33 & 11.00 & 4.84 & 34.67 & 100 \\
\hline $\mathbf{4 .}$ & $\mathrm{T} 4$ & $75 \mathrm{~Gy}$ & 54.06 & 5.13 & 11.40 & 4.79 & 30.87 & 100 \\
\hline $\mathbf{5 .}$ & $\mathrm{T} 5$ & $100 \mathrm{~Gy}$ & 53.02 & 4.87 & 11.47 & 4.73 & 29.40 & 96 \\
\hline $\mathbf{6 .}$ & $\mathrm{T} 6$ & $125 \mathrm{~Gy}$ & 52.62 & 4.80 & 11.67 & 4.64 & 28.80 & 96 \\
\hline $\mathbf{7 .}$ & $\mathrm{T} 7$ & $150 \mathrm{~Gy}$ & 52.10 & 4.20 & 12.07 & 4.58 & 27.53 & 92 \\
\hline S.E $\mathbf{5}$ & & & 0.79 & 0.29 & 0.16 & 0.10 & 0.59 & 2.54 \\
\hline C.D at 5\% & & & 2.45 & 0.91 & 0.50 & 0.31 & 1.83 & NS \\
\hline
\end{tabular}

Bhusari A.V. 2015.

Table.2 Effect of growing system and root treatment on yield and quality of Anthurium

\begin{tabular}{|c|c|c|c|c|c|c|c|}
\hline $\begin{array}{c}\text { Growing } \\
\text { system }\end{array}$ & $\begin{array}{c}\text { Root } \\
\text { treatment }\end{array}$ & $\begin{array}{c}\text { Flower } \\
\text { stalks/plant } \\
\text { (No) }\end{array}$ & $\begin{array}{c}\text { Stalk } \\
\text { length } \\
\text { (cm) }\end{array}$ & $\begin{array}{c}\text { Flower } \\
\text { spathe width } \\
\text { (cm) }\end{array}$ & $\begin{array}{c}\text { Leaves/ } \\
\text { plant } \\
\text { (No.) }\end{array}$ & $\begin{array}{c}\text { Leaf petiole } \\
\text { length } \\
\text { (cm) }\end{array}$ & $\begin{array}{c}\text { Leaf } \\
\text { Lamina } \\
\text { Size }\left(\mathbf{c m}^{2}\right)\end{array}$ \\
\hline Aeroponic & Cut roots & 1.8 & 44.6 & 8.0 & 2.5 & 40.9 & 397.0 \\
\hline & control & 2.6 & 49.7 & 8.9 & 3.4 & 43.5 & 402.5 \\
\hline Soilless & Cut roots & 2.4 & 37.6 & 8.8 & 2.1 & 32.6 & 327.9 \\
\hline & control & 2.6 & 45.2 & 9.4 & 1.9 & 39.8 & 3.47 .9 \\
\hline Significance & & & & & & & \\
\hline System root & $\mathrm{Ns}$ & $*$ & $*$ & $*$ & $*$ & $*$ & $*$ \\
\hline Treatment & $\mathrm{ns}$ & $*$ & $*$ & $*$ & $*$ & $*$ & $\mathrm{~ns}$ \\
\hline Interaction & $\mathrm{ns}$ & $*$ & $*$ & $*$ & $*$ & $*$ & $*$ \\
\hline
\end{tabular}

$\mathrm{ns}=$ not significant, $*=$ significant at $\mathrm{P} \leq 0.05 * *=$ significance at $\mathrm{P} \leq 0.01$ (Duuncan's multiple range test).

G. Fascella and G.V. Zizzo2007. 
Table.3 Proposed increment of the amount of green lands and plants after the usage of vertical gardens on hotels and shopping malls in Antalya

\begin{tabular}{|l|l|l|l|l|l|}
\hline Place & Number & $\begin{array}{l}\text { Vertical } \\
\text { garden }\end{array}$ & $\begin{array}{l}\text { Amount of } \\
\text { plants } \\
\mathbf{m}^{2}\end{array}$ & $\begin{array}{l}\text { Total vertical } \\
\text { each } \\
\text { gardens } \mathbf{m}^{2}\end{array}$ & $\begin{array}{l}\text { Total } \\
\text { amount } \\
\text { plants }\end{array}$ \\
\hline Hotels & 1400 & 200 & 60 & 280,000 & $16,800,000$ \\
\hline $\begin{array}{l}\text { Shopping } \\
\text { malls }\end{array}$ & 10 & 450 & 60 & 4500 & 270,000 \\
\hline Total & & & 284,500 & $17,070,000$ \\
\hline
\end{tabular}

Table.4 Effect of drying method on time taken for drying of silver oak (Grevillea robusta), thuja (Thuja orientalis) and camellia (Camellia reticulata) with different drying agents

\begin{tabular}{|c|c|c|c|c|c|c|}
\hline Treatment & \multicolumn{3}{|c|}{ Duration of drying } & \multicolumn{3}{c|}{ Moisture loss (\%) } \\
\hline & Silver oak & Thuja & Camellia & Silver oak & Thuja & Camellia \\
\hline Air drying & 3.6 days & 10 days & 8.2 days & 43.53 & 44.33 & 53.12 \\
\hline Sand drying & 5.8 days & 18 days & 14.0 days & 38.77 & 47.38 & 46.58 \\
\hline Microwave drying & 1.36 min & 3.36 min & 3.29 min & 42.56 & 53.27 & 61.18 \\
\hline Glycerinization(full dip) & 3.4 days & 2.0 days & 6.0 days & 11.62 & 15.72 & 19.8 \\
\hline Glycerinization (uptake) & 2.0 days & 12.0 days & 10.2 days & 17.3 & 13.24 & 15.6 \\
\hline SEm \pm & 0.379 & 0.447 & 0.932 & 2.5 & 1.3 & 1.3 \\
\hline CD $(\mathrm{P}=0.05)$ & 0.791 & 0.932 & 1.08 & 5.2 & 2.7 & 2.9 \\
\hline
\end{tabular}

Table.5 Sensory score on overall acceptability of flowers of chrysanthemum (yellow and green), gerbera and plumeria with various drying agents with microwave drying

\begin{tabular}{|l|l|l|l|l|}
\hline Treatment & $\begin{array}{l}\text { Sensory scores } \\
\text { Chrysanthemum } \\
\text { (yellow) }\end{array}$ & $\begin{array}{l}\text { Chrysanthemm } \\
\text { (green) }\end{array}$ & Gerbera & Plumeria \\
\hline Sun drying & 0.76 & 0.78 & 0.78 & 0.76 \\
\hline Sand drying & 2.83 & 2.82 & 2.68 & 2.8 \\
\hline Silica drying & 3.02 & 3.06 & 2.77 & 3.03 \\
\hline borax & 0.00 & 0.0 & 0.0 & 0.0 \\
\hline Silica + & 3.56 & 3.57 & 3.53 & 3.55 \\
\hline Sand drying & & & & \\
\hline Borax + & 0.0 & 0.0 & 0.0 & 0.0 \\
\hline sand drying & & & & 0.054 \\
\hline SEd \pm & 0.13 & 0.065 & 0.09 & 0.12 \\
\hline $\mathrm{CD}(\mathrm{P}=0.05)$ & 0.06 & 0.130 & 0.18 & Jawaharla et al., 2013. \\
\hline
\end{tabular}


Table.6 Visual score on overall acceptability of dried leaves of silver oak, thuja and camellia

\begin{tabular}{|c|c|c|c|}
\hline \multirow{2}{*}{ Treatment } & \multicolumn{3}{|c|}{ Sensory score } \\
\cline { 2 - 4 } & Silver oak & Thuja & Camellia \\
\hline Air drying & 1.99 & 1.82 & 0.35 \\
\hline Sand drying & 2.50 & 1.66 & 1.30 \\
\hline Microwave drying & 2.02 & 1,44 & 0.76 \\
\hline Glycerinization(full dip) & 3.70 & 3.87 & 3.70 \\
\hline Glycerinization (up take) & 3.18 & 3.08 & 2.74 \\
\hline SEm \pm & 0.15 & 0.13 & 0.17 \\
\hline CD $(\mathrm{P}=0.05)$ & 0.28 & 0.26 & 0.35 \\
\hline
\end{tabular}

Jawaharlal et al., 2013.

While green facades have soil only at the base of the wall and support climbing plants on the face of the wall to create the green, or vegetated, facade. The plants receive water and nutrients from within the vertical support instead of from the ground. In vertical gardens, various types of modular panels can be used along with geo-textile fabrics, growing media, irrigation systems, and plants. Living walls are particularly suitable for cities, as they allow good use of available vertical surface areas. The living wall could also function for urban agriculture, urban gardening, or for its beauty as art. Green walls may be indoors or outside, freestanding or attached to an existing wall, and come in a great variety of size.

Analysis of contribution of vertical gardens to urban sustainability: the case study of Antalya city, Turkey

\section{Techniques in dry flower making}

Drying: Natural drying, Air drying, Press drying, Freeze drying, Water drying. Embedding: Sun drying, Oven drying, Microwave oven drying, solar dryer drying, Vacuum drying.

Dyeing: Dip dyeing, Spry dyeing, Absorbing.

Bleaching

\section{Drying}

Drying is a process to dry something under artificial produced heat though controlled temperature, humidity and air flow. Dry flower constitute more than two-thirds of total floricultural export. Dry flower constitute nearly $15 \%$ of the global floriculture business and form the major share in Indian floricultural exports as well. The demand for flowers is increasing at an impressive rate $8-10 \%$. Drying of flowers does not mean only flower but also includes dried shoots, seeds, pods and bar (Table 4).

\section{Standardization for drying, bleaching and dyeing processes in dried flowers}

\section{Embedding}

In this method, retention of flower colour and shape is good. After harvesting and preparing, the flower are placed in desiccants like sand, silica gel, boric acid, borax, saw dust, alum powder, aluminium sulphate corn granules etc. Borax mixed with sand or cornmeal. Silica gel is an excellent product for drying flowers.

It is while but some types container blue crystals that act as an indicator of amount of moisture absorbed. Shallow container should be used. 


\section{Dyeing}

Dyeing of ornamental plant material is considered much as an art. Accordingly, determining the optimum treatment protocol for a particular product is often a matter of systemic trial and error. Immersion dyeing is improved by removing the waxy cuticle with $\mathrm{NAOH}$ from dried plant material.

Adding surfactants to improve the contact between the dye bath solution and the plant material. In addition to dyeing, which is properly called staining, the plant material can also be coloured by painting and commonly silver or golden paint is used.

\section{Standardization for drying, bleaching and dyeing processes in dried flowers}

\section{Bleaching}

Bleached ornamental plant material provides a striking contrast when arranged with dried or dyed flowers. Bleaching also allows the use of dyes for coloring. Oxidative (Hypochlorite, Chlorite and Peroxide) and reductive bleaching chemicals (Sulphite and Borohydride) are used for bleaching ornamental flowers and foliage. Sodium Chlorite is an excellent bleaching agent because it is relatively selective for lignin without damaging fibre. In reductive bleaches, hydrosulphites (Sodium or Zinc Hydrosulphite) are cheap and have maximum bleaching power.

Coloring Dried Flowers Preserving flowers with their natural colour is essential otherwise we have to improve the colour of the product by adding dyes.

A dye is most often added to the glycerin preserving solution to permanently colour the decorative plant materials. Systemic dyes are available for use. They are acidic- anionic dyes, which are combined with water and glycerin to form a preservation solution that is absorbed by fresh cut flowers and foliage through the stem of the plant. Normally $1.5 \mathrm{ml}$ to $5 \mathrm{ml}$ dye/l of solution is prepared. Color take and preservation will take 28 days.

In conclusion, floriculture thrives on novelty and is the necessity of stimulating processes as prospective means to catch up the global business. The result of the research on flower color, flower form, plant architecture, scent emission, production and post-harvest technologies and value addition lead to the commercialization of novel innovations which are readily utilized in the market.

In fact, the level of understanding in the genetics and molecular mechanisms as well as new approaches were tested which served as a basis for a gradual change from chemical to biotechnological tools in floriculture.

More conscious efforts are the need of the hour to address biotic and abiotic stresses, quality planting material, standardization the propagation techniques, exploiting new ornamentals and pole to post promotion of floriculture of floriculture for socioeconomic sustainability.

\section{References}

Anil, K. 2019. Value addition in floriculture. Department of Horticulture, Institute of Agriculture Sciences, Banaras Hindu University, Varanasi-221 005, U.P., India.

Anil, K. Singh and Anjana S. 2017. Textbook of floriculture and Landscaping. New India Publishing Agency, 245: 224-259.

Arvind, S. 2019. Vertical garden interventions at agro tourism center CCS HAU Hisar. Assistant Professor (Horticulture) Agri tourism Center. CCS Haryana Agriculture, University Hasir-125004. 
Bhusari, A. V. 2015. "Effect of gamma irradiation on morphological characters of marigold (Tagetes erecta L.)" College of agriculture, Pune. Mahatma phule krishividyapeeth, Rahuri-413722, Dist. Ahmednagar Maharashtra State (India).

Chen, C., Hou, Zhang, H., Wanf, G., and Tian, L. (2011). Induction of Anthrium andraeanum "Ariona" tetraploid by colchicine in vitro. Euphytica, 18(2), 137145.

Debener, T. 1999. Genetic analysis of horticulturally important morphological and physiological characters in diploid roses. Gartenbauwissenshaft, 64(1), 4-19.

Fascella, G. and Zizzo, G.V. 2007. Preliminary Results of Aeroponic Cultivation of Anthuriumandreanum for Cut Flower Production. Istituto Sperimentale per la Floricoltura - Sezione di Palermo S.S. 113 Km 245.500 - 90011 Bagheria

Jain, S.M., Vitti, D., Tucci, M., Grassotti, A., Rugini, E., and Saccardo, F. 1998. Biotechnology and mutagenesis in gerbera improvement. Advances in horticulture science, 47-53.

Janakiran, T. and Lakshmi Durga 2019. Novel Innovation in Floriculture. Assistant Director General, Horticultural Science Division, ICAR, KAB New Delhi.

Jawaharlal, M., Visalakshi, M., Cintu, S., and Ganga, M. 2013. Standardization for drying, bleaching and dyeing processes in dried flowers. Tamil Nadu Agricultural University Coimbatore - 641003, India.

Kumari, L., Raunak, S. and Ashish G. 2019. Dry flower production and dry flower products. Department of Horticulture, SKRAU, Bikaner, Rajathan.
Noor, S.H., Ushijima, K., Murata, A., Yoshida, Tanabe, M., Tanigawa, T, AND Nakano, $R$ (2014). Double flower formation induced by silencing of C-class MADSbox genes and its variation among perunia cultivar. Scienta Horticulture, 178, 1-7.

Okamaru, M., Yasuno, N., Ohtusuka, Tanaka, A., Shikazono, N., Hase, Y. (2003). Wide variety of flower-color and shape mutants regenerated from leaf irradiated with ion beams. Nuclear Instructions and Methods in Physics Research Section B: Beam Interactions with Materails and Atoms, 206, 574-578.

Patel, Dishaben K. and Chawla S.L. (2019). Hydroponics: A modern technology supporting the application of integrated crop management. Floriculture and Landscaping Architecture, Department of Horticulture, College of Agriculture, J.A.U.., Gujarat, India.

Srovastva, R., Datta, S.k., Sharma, S.C., and Roy, R.K. (2002). Gamma rays induced genetic variability in Bougainvellia. J. Nuclear Agriculture and Biology, 31(1), 28-36.

Yamaguchi, H., Nagatomi, S., Morishita, T., Degi, K., Tanaka, A., Shikazono, N., and Hase, Y. (2003). Mutation induced with ion beam irradiation in rose. Nuclear Instructions and methods in Physics Research Section B: Beam Interations with Material and Atoms, 206, 561-564.

Zuhal, K., Latif, G., Hakan, E. 2013. Analysis of contribution of vertical gardens to urban sustainability: The case study of Antalya city, Turkey. İnönü University. Journal of Art and Design. Cilt/Vol. 3Say1/No.7 (2013): 55-59.

\section{How to cite this article:}

Chavan, V.B., S.P. Khedkar, B.R. Salvi, Y.R. Parulekar and Dalvi, N.V. 2019. Novel Innovations in Floriculture Industry. Int.J.Curr.Microbiol.App.Sci. 8(06): 1855-1863.

doi: https://doi.org/10.20546/ijcmas.2019.806.221 